\title{
The Influence of Personality, Motivation, Brand Image, and Environment on Students' Intention in Choosing Bogor Agricultural University (IPB)
}

\author{
Aris Solikhah* \\ Graduate School of Management \\ Business, Bogor Agricultural \\ University
}

\author{
Hartoyo \\ Department of Family and \\ Consumer Sciences, \\ Faculty of Human Ecology, \\ Bogor Agricultural University
}

\author{
Lilik Noor Yuliati \\ Department of Family and \\ Consumer Sciences, \\ Faculty of Human Ecology, \\ Bogor Agricultural University
}

*Corresponding author: aris.solikhah@gmail.com

\begin{abstract}
The research aimed to identify the level of intention and analyze the influence of personality, motivation, brand image, and environment on intention of the top 15 grade of 11 Science students from 14 high schools in Jakarta, Bogor, Depok, Tangerang, and Bekasi to choose IPB and its managerial implications. Questionnaire with Likert scale was used as a method in collecting data. Descriptive and Structural Equation Modeling (SEM) was used in analyzing data. The results showed that one of three students intended to apply to IPB as a sequence of first choice and second choice. Brand image and motivation significantly influenced the students' intention in choosing IPB. Environment and personality did not influence the intention. Environment significantly influenced brand image and students' motivation. Personality did not influence the motivation, brand image, and intention. Making marketing strategies related to students' intention, IPB should consider motivational factors; e.g., students' preference in science and agricultural technology, brand image (good reputation), and environment (counseling teachers' advice and access to the internet/website) in choosing a college as a main factor.
\end{abstract}

Keywords: brand image, environment, intention to choose IPB, motivation, personality

\begin{abstract}
Abstrak. Penelitian bertujuan mengidentifikasi tingkat niat dan menganalisis pengaruh kepribadian, motivasi, brand image, dan lingkungan terhadap niat 15 siswa terbaik IPA kelas XI tahun ajaran 2014/2015 di 14 SMA JABODETABEK dalam memilih IPB serta implikasi manajerialnya. Metode pengambilan data menggunakan kuesioner dengan skala likert. Analisis data yang digunakan deskriptif dan Structural Equation Model (SEM). Hasil penelitian ini menunjukkan satu dari tiga siswa berniat mendaftar ke IPB sebagai urutan pilihan pertama dan pilihan kedua. Brand image dan motivasi berpengaruh signifikan terhadap niat siswa memilih IPB. Lingkungan dan kepribadian tidak berpengaruh terhadap niat. Lingkungan berpengaruh signifikan terhadap brand image dan motivasi siswa. Kepribadian tidak berpengaruh terhadap motivasi, brand image, dan niat. IPB dalam membuat strategi pemasaran yang berhubungan minat siswa hendaknya mempertimbangkan faktor motivasi (menyukai bidang sains dan tekologi bidang pertanian), brand image (reputasi baik) dan lingkungan (pertimbangan guru Bimbingan Konseling dan akses internet/website) dalam memilih perguruan tinggi sebagai faktor utama.
\end{abstract}

Kata kunci: brand image, kepribadian, lingkungan, motivasi, niat memilih IPB 


\section{Introduction}

Globalization has brought enormous implications on the sector of business services, especially colleges in Indonesia. The competition of colleges to attract prospective students is increasingly stringent. It is also due to the increasing number of colleges in both public and private sectors in and outside the country that made the capacity increase during the last 14 years (2000-2014). According to Forlapdikti (2014), in 2000 the number of Private Colleges (PTS) and State Colleges (PTN) was as many as 76 to 348 and 1.671 and 3.980 in 2014. The number of students increased from 924.092 in 2000 to 5.119.206 in 2014. The high offer rate of domestic and foreign colleges has given a lot of alternative options for students to pursue higher education. It is very important to beknown the students' decision-making process in choosing a certain college. Therefore, the managers of higher education should indentify it through the study of consumer behavior because it is an important process influenced by the external environment consisting of the marketing mix (product, promotion, price, distribution), socio-cultural environment (family; information source; non-commercial source; social class; personal, family, cultural and sub-cultural influence) and internal environmentor psychological factors (motivation, personality, learning, perception and attitude) (Schiffman and Kanuk, 2007).

Research on consumer behavior, mainly an interest on educational services, especially college has increased along with the awareness of stakeholders that understand and meet the desires and needs of customers as a way to sustain their business (Kotler and Andreasen, 1995) and to devise a marketing strategy for educational institutions (Wijaya, 2012; Ristiyanti and Ihalauw, 2005). The reason of this is because the educational service is a an organization of production that produces educational services (Alma and Huriyati, 2008). The main consumers are the school students or college students (Srinadi and Nilakusmawati, 2008).

Domestic and foreign researchers have done some research on intention and behavior of selecting college. The influential factors are the state of country's economy and career opportunities in agriculture (Onu and Ikehi, 2013); international accreditation, educational facilities, the flexibility of learning time (Fosu and Poku, 2014), the influence of family and friends (Andanawari, 2010; Azubuike, 2011; Kitsawad, 2013; Nassif, 2011); Furukawa, 2011), recommendation of teachers (Kyalo and Chumba, 2011; Tran, 2012; Herren, Cartwell, and Robetson, 2011), information factors (open houses, exhibitions, mass media), economic factors (cost of education, career prospects), geographical location, school ranking, and individual skills (Eidimtas and Jucevience, 2014; Lee and Chatfield, 2011; Wagner and Fard, 2009), socioeconomic factors, (Misran et al., 2012), motivation (Anderson, 2013; McEown, Noels, Saumure, 2014; Martini, 2013; Razak, 2008) and personality (Smith, 2010; Ciriaka et al., 2014).

Vrontis, Trasshou, and Melanthiou (2007) in their research have made a model of contemporary students in choosing a college in developed countries, but this has not been tested as a model to choose colleges in developing countries, especially Indonesia. In addition, from these studies, they have never investigated the relationship between personality, motivation, brand image, and the environment on the intention of high school students in choosing a college in Indonesia in a research model simultaneously.

Bogor Agricultural University (IPB) as one of the Legal Entity State Colleges (PTN-BH) implements promotional strategies to disseminate acceptance and attract the 
interest of new students as an effort to expand access and improve the number of applicants of agricultural higher education (IPB, 2013b). A total number of applicants who chose IPB as the first choice increased from 25.781 in 2011 to 56.871 in 2013 (IPB, 2013a). It is because of the changes in student admission policies at the national level, in which college students can choose higher education institution according to their interests. In general, enthusiasts of agricultural studies program tend to decrease nationally and internationally. In the United States, the Philippines and Japan, there is a decline in the number of students of agricultural groups (Manuwoto and Firdaus, 2010). In the period of 2005-June 2006, there were 40 faculties of agriculture that were closed (Chozin, 2008). Nowadays, the trend of the student's interest has shifted to socioeconomic field (Santoso, 2013).

Some factors that influence the trend are; students' motivation to get a guarantee in having the job (Esters and Bowen, 2005), the brand image of agriculture, changes in consumer behavior, marketing activities and internal conditions of the college which are less attractive for new students (Fritz et al., 2007) to continue their higher education in agriculture. IPB as an agricultural college always tries to maintain the quality of its inputs by seeking and accepting new students who get the best grades in their schools.

By knowing the factors that influence the intention of students who are in the top 15 ranking in high school based on PERAKS (Performance of School Academic History) owned by IPB, especially in Jakarta, Bogor, Depok, Tangerang, and Bekasi (Jabodetabek) where every year the number of IPB students mostly graduates from high school in those area, IPB can make the priority program of marketing activities (promotion) in order to maintain the quality of its inputs.

Information concerning influential factors of students' intention, especially those who are at the top 15 in science class is still minimum. The objectives of this research were: (1) to identify the level of intention of the top 15 high school students in choosing IPB; (2) to analyze the influence of personality, motivation, individual characteristics, brand image and the environment on the intention of the best students in choosing IPB; and (3) to formulate the managerial implications on IPB policy, particularly those which are related to marketing or promotion.

\section{Method}

This research was conducted through a survey of 210 grade 11 science students in the academic year of 2014/2015. Samples were top 15 students in 14 high schools in Jabodetabek selected by purposive sampling. The selected schools listed on the Performance of School Academic History (PERAKS) become the destination of college promotion activities, and they are not on IPB black list. PERAKS is a database that contains excellent schools owned by IPB since 1982. The selection of high school origin is also based on public and private categories including cities and regencies in Jabodetabek.

Data were collected by questionnaires, and Likert scale was used as measuring tools. The reliability of measuring tools had been tested with Cronbach's alpha values and its validity had also been tested by comparing r-value and r-table. Data were analyzed using descriptive analysis (percentage, flats, crosstab, and chi-square) and Structural Equation Modelling (SEM) using Smart PLS software. The research model can be seen in Figure 1. 


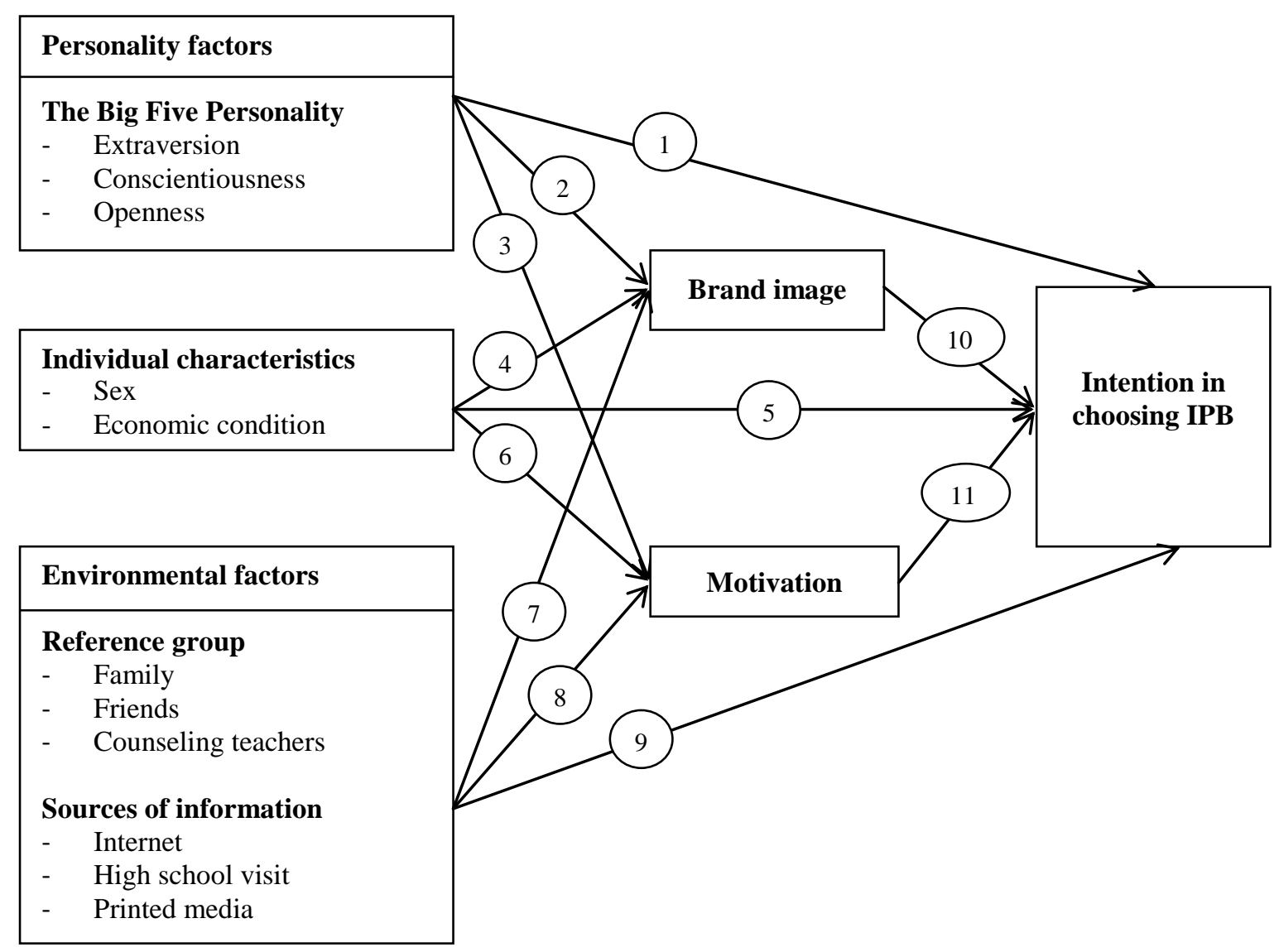

Figure 1 Research model

The research hypotheses are as follows:

1. Personality factors affect the intention in choosing IPB

2. Personality factors affect the brand image

3. Personality factors affect the motivation

4. Individual characteristics affect the brand image

5. Individual characteristics affect the intention in choosing IPB

6. Individual characteristics affect the motivation

7. Environmental factors affect the brand image

8. Environmental factors affect the motivation

9. Environmental factors affect the intention in choosing IPB

10. Brand image affects the intention in choosing IPB

11. Motivation affects intention in choosing IPB

12. Environmental factors indirectly affect intention in choosing IPB through brand image

13. Environmental factors indirectly affect intention through motivation

14. Individual characteristics indirectly affect the intention in choosing IPB through brand image

15. Individual characteristics indirectly affect intention through motivation

16. Personality factors indirectly affect intention in choosing IPB through brand image

17. Personality factors indirectly affect intention in choosing IPB through motivation 


\section{Results}

Most students in this research were female $(66 \%)$ with expenditure per month ranging from $\mathrm{Rp} 216.000$ to $\mathrm{Rp} 3.63$ million, and the average expenditure was Rp1.268.434. The expenditure per month covered meal and transportation allowance, tutoring cost, the cost for books or copying documents, and any others. The result showed that more than half of students chose the University of Indonesia (UI) as the first and second choice, while IPB occupied the second and third position of choice (Table 1).

Table 1 List of first choice (U1) dan second choice (U2) of higher education institution

\begin{tabular}{lcccc}
\hline College & U1 & $\%$ & U2 & $\%$ \\
\hline UI & 68 & 32.3 & 80 & 38.0 \\
ITB & 49 & 23.3 & 29 & 13.8 \\
IPB & 40 & 19.0 & 37 & 17.6 \\
UGM & 17 & 8.0 & 34 & 16.1 \\
Others & 36 & 17.1 & 30 & 14.3 \\
\hline
\end{tabular}

The reasons why they chose UI as the first priority are as follows; a very good reputation and accreditation, the guarantee of graduates' future, a close to home location; an ideal college since child, an affordable tuition, a recommended university, and desired departments. Meanwhile, Bandung Institute of Technology (ITB) was chosen in the second place of the first choice for some reasons; a good reputation, a best graduates-producing university, a strong alumni bond, a comfortable environment, the guarantee of graduates' future, the best college in the field of engineering and technology, good lecturers and facilities, an ideal college since child, and desired departments.

The analysis of cross-tabulation between students' intention and preferences in choosing IPB showed that the number of students chose IPB as their first choice (19\%), second choice $(17.6 \%)$, third choice $(18 \%)$, fourth choice $(33.8 \%)$, and fifth choice $(11.4 \%)$. The chi-square test analysis has also proved the significant association between the intention in choosing IPB with IPB selection as the first, second, third, fourth, or fifth choice ( $\mathrm{p}$-value $=0.000$ at 0.05 level).

There were some students' perception toward colleges' brand image, i.e., having a good reputation, promoting agriculture, providing the ease of getting a job for the graduates, having affordable tuition, and having good academic quality. The results showed the order as follows: IPB (4.14), UI (3.91), ITB (3.89), and UGM (3.87) respectively (Table 2). Having this position, IPB needs to increase the efforts to improve its brand image that relates especially to a good reputation, the ease of getting a job, and a good academic quality.

Based on the results, most students (91\%) knew IPB from edufair (22\%), college visit (8\%), internet (28\%), parents (31\%), and counseling teachers (12\%). The information from parents is the most, while from school visits is the least.

Table 2 The mean score of students to the college's brand image

\begin{tabular}{lcccc}
\hline Brand image & IPB & UI & UGM & ITB \\
\hline Good reputation & 4.17 & 4.33 & 4.22 & 4.32 \\
Ease of getting a job (bright future) & 3.99 & 4.25 & 4.07 & 4.18 \\
Affordable tuition & 3.7 & 3.25 & 3.38 & 3.34 \\
Good academic quality & 4.21 & 4.4 & 4.3 & 4.33 \\
\hline Mean & 4.02 & 4.06 & 3.99 & 4.04 \\
\hline
\end{tabular}


Prediction analysis of factor model that influence the intention of selecting IPB can be seen from the analysis of measurement model (outer model) and analysis of structural models (inner model) using Structural Equation Modelling (SEM) and Smart PLS software. Measurement model analysis is a factor analysis using the method of confirmatory performed to obtain measurable variables that can be the indicators of a latent variable. Construct validity showed how well the results were obtained from the use of appropriate measurement theories used to define a construct (Jogiyanto, 2011). The construct validity consisted of convergent and discriminant validity. Construct validity test can generally be measured by a score of loading parameter in the model of research (Rule of Thumbs > 0.7) and use the AVE parameter, Communality, R2, and Redundancy close to 1.

If the loading score is $<0.5$, the indicator can be removed from its construct as this indicator is not loaded to the representative construct. If the loading score is between 0.5 to 0.7 , researchers should not remove an indicator that has loading score along with AVE score and communality indicators that are more than 0.5 (Jogiyanto, 2011).

Based on the results of the factor analysis, the factor loading values obtained ranged from -0.6764 to 0.9571 . The measured variables chosen as indicators are variables that have a charge of the factor that is greater than 0.50 (Hair et al, 2008).

Some indicators have loading value that is smaller than 0.5 or even negative among others, namely gender (JK) on individual variables; I chose a college because it opens the courses I am interested in (MOTIV3), I was a little sloppy (CONS2), I am a students who are reliable (CONS3), I tend to be irregular (CONS4), I tend to be lazy (CONS5), I like something that is efficient (CONS7), I am easily distracted (CONS9), I tend to be quiet (EXTRA5), I am sometimes shy (EXTRA7), I am happy to go out and socialize (EXTRA8), I love the work routine (OPEN7), I am less interested in something that is both artistic (OPEN9), and I have little interest in art (OPEN10) on personality variables. Indicators are further removed (drop) and cannot be used as an indicator in research model (Table 3). However, gender indicator does not drop specifically because of the control variables.

Based on the comparison of AVE root value and correlation coefficient between variables, it is shown that the measurement (indicators) used in this research meet the criteria of discriminant validity. This is because the AVE root for each construct is larger than the correlation between other constructs in the model. Cross loading also shows the value of each indicator that exists in a latent variable that has differences with other variables indicated by a higher loading score and accumulate in its construct. Thus, we can conclude that the data have met the test of discriminant validity. In addition to the validity of the test, the tests were also done to measure the reliability of internal consistency and accuracy of measuring devices. Reliability test in PLS can use two methods of Cronbach's alpha and composite reliability. 
Table 3 Construct, indicator variables and value loading factor Phase II

\begin{tabular}{|c|c|c|}
\hline Construct and indicator variable & Symbol & $\begin{array}{l}\text { Loading } \\
\text { factor }\end{array}$ \\
\hline \multicolumn{3}{|l|}{ Personality } \\
\hline \multicolumn{3}{|l|}{ A. Openness } \\
\hline 1. I have the originality and often comes up with new ideas & OPEN1 & 0.796 \\
\hline 2. I have a high curiosity about many things & OPEN2 & 0.658 \\
\hline 3. I am a cunning and a deep thinker & OPEN3 & 0.709 \\
\hline 4. I have an active imagination & OPEN4 & 0.757 \\
\hline 5. I have inventive spirit (like to find something new) & OPEN5 & 0.718 \\
\hline 6. I have artistic soul and aesthetic experience & OPEN6 & 0.539 \\
\hline 7. I like to reflect and play with ideas & OPEN8 & 0.557 \\
\hline \multicolumn{3}{|l|}{ B. Conscientiousness } \\
\hline 1. I did a thorough job & CONS1 & 0.790 \\
\hline 2. I tend to be lazy & CONS6 & 0.701 \\
\hline 3. I like something that is efficient & CONS8 & 0.660 \\
\hline \multicolumn{3}{|l|}{ C. Extraversion } \\
\hline 1. I am talkative & EXTRA1 & 0.747 \\
\hline 2. I am protective & EXTRA2 & 0.559 \\
\hline 3. I am energetic & EXTRA3 & 0.845 \\
\hline 4. I have a lot of enthusiasm & EXTRA4 & 0.784 \\
\hline 5. I have a firm personality & EXTRA6 & 0.599 \\
\hline \multicolumn{3}{|l|}{ Environment } \\
\hline \multicolumn{3}{|l|}{ A. Reference group } \\
\hline 1. Parents are very influential on choosing college & KA1 & 0.698 \\
\hline $\begin{array}{l}\text { 2. Consideration of counseling teachers is a great influence on choosing } \\
\text { college }\end{array}$ & KA2 & 0.839 \\
\hline 3. Consideration of friends is a great influence on choosing college & KA3 & 0.650 \\
\hline \multicolumn{3}{|l|}{ B. Exposure information } \\
\hline $\begin{array}{l}\text { 1. I frequently access the internet/website for seeking college } \\
\text { information }\end{array}$ & PI1 & 0.777 \\
\hline 2. I often attend Edufair, educational fairs, campus visits, and I study & & 0.756 \\
\hline various colleges & PI2 & \\
\hline 3. I often receive information about colleges from brochure, print media, & & 0.765 \\
\hline posters, magazine, and other print media & PI3 & \\
\hline \multicolumn{3}{|l|}{ Individual characteristics } \\
\hline 1. Gender & JK & -0.263 \\
\hline 2. Economic conditions & $\mathrm{KE}$ & 0.976 \\
\hline \multicolumn{3}{|l|}{ Intention to choose IPB } \\
\hline 1. I am interested in entering IPB & MINAT1 & 0.962 \\
\hline 2. I would like to find more in-depth information about IPB & MINAT2 & 0.953 \\
\hline \multicolumn{3}{|l|}{ Brand image } \\
\hline 1. Good reputation & B.IMAGE1 & 0825 \\
\hline 2. Improving national agriculture (food and environment) & B.IMAGE2 & 0.545 \\
\hline 3. Ease of getting a job for alumni (bright future) & B.IMAGE3 & 0.770 \\
\hline 4. An affordable cost of education & B.IMAGE4 & 0.545 \\
\hline 5. Good quality of academic & B.IMAGE5 & 0.816 \\
\hline \multicolumn{3}{|l|}{ Motivation } \\
\hline 1. I chose a college that is located close to home & MOTIV1 & 0.612 \\
\hline $\begin{array}{l}\text { 2. I am interested in choosing a college because of its simplicity in } \\
\text { providing scholarships }\end{array}$ & MOTIV2 & 0.577 \\
\hline 3. I like science and technology in agriculture & MOTIV5 & 0.855 \\
\hline
\end{tabular}


Composite reliability is assessed better in estimating the internal consistency of a construct. Rule of thumb of alpha value or composite reliability should be greater than 0.7 even if the value of 0,6 is acceptable (Hair et al., 2008). Latent variables (Table 4) has a value of RD $>0.5$ and composite reliability of $\geq 0.7$. It can be concluded that the indicators used are the variables having fairly good reliability or able to measure its construct. These variables include the brand image, individual characteristics, intention, conscientiousness, extraversion, reference group, and exposure information. Personality latent variables, motivation, environment and openness have AVE value $<0.5$ and composite reliability $\geq 0.7$. These values showed that the indicator of personality latent variables, motivation, environment and openness were reliable, but has a fairly weak convergent validity.

Table 4 Testing the validity and reliability

\begin{tabular}{lcccc}
\hline Variable & AVE & Composite reliability & R Square & Cronbach's alpha \\
\hline Personality & 0.3245 & 0.8745 & & 0.8446 \\
Openness & 0.4656 & 0.8570 & 0.8142 & 0.8040 \\
Extraversion & 0.5116 & 0.8365 & 0.6682 & 0.7512 \\
Conscientiousness & 0.5171 & 0.7616 & 0.3391 & 0.5291 \\
Motivation & 0.3478 & 0.7214 & 0.2189 & 0.5491 \\
Brand image & 0.5070 & 0.8326 & 0.0909 & 0.7470 \\
Environment & 0.3088 & 0.7201 & & 0.5396 \\
Reference group & 0.5377 & 0.7751 & 0.3976 & 0.5701 \\
Information exposure & 0.5868 & 0.8099 & 0.6919 & 0.6489 \\
Individual & 0.5132 & 0.2892 & & -0.0942 \\
Intention & 0.9176 & 0.9571 & 0.4624 & 0.9104 \\
\hline
\end{tabular}

From the analysis of structural models (inner model), based on the results of data processing (Figure 2), the R-square value of students' intention in choosing IPB was 0.4781 . It means that the latent variables of intention can be explained by a latent variable of motivation factor and brand image of 47.81 percent, while the rest is explained by other variables. The hypothesis of the research tested the bootstrap technique in Smart PLSs. Testing hypotheses raised in this research can be seen in Table 5.

Table 5 Value path coefficients (path coefficient)

\begin{tabular}{lccccc}
\hline Path & $\begin{array}{c}\text { Original } \\
\text { sample } \\
(\mathrm{O})\end{array}$ & $\begin{array}{c}\text { Sample } \\
\text { mean }(\mathrm{M})\end{array}$ & $\begin{array}{c}\text { Standard } \\
\text { deviation } \\
(\mathrm{STDEV})\end{array}$ & $\begin{array}{c}\text { Standard } \\
\text { error } \\
(\text { STERR })\end{array}$ & $\begin{array}{c}\text { T statistics } \\
(|\mathrm{O} / \mathrm{STERR}|)\end{array}$ \\
\hline Personality -> Intention & -0.026 & -0.024 & 0.060 & 0.060 & 0.444 \\
Personality -> Brand Image & 0.016 & 0.025 & 0.086 & 0.086 & 0.191 \\
Personality -> Motivation & -0.041 & -0.044 & 0.069 & 0.069 & 0.600 \\
Brand Image -> Intention & 0.245 & 0.243 & 0.058 & 0.058 & $4.223^{* *}$ \\
Motivation-> Intention & 0.523 & 0.526 & 0.050 & 0.050 & $10.440^{* *}$ \\
Environment -> Brand Image & 0.294 & 0.298 & 0.077 & 0.077 & $3.815 * *$ \\
Environment -> Motivation & 0.432 & 0.432 & 0.085 & 0.085 & $5.104 * *$ \\
Environment -> Intention & 0.085 & 0.079 & 0.060 & 0.060 & 1.435 \\
Individual -> Motivation & -0.048 & -0.071 & 0.079 & 0.079 & 0.612 \\
Individual -> Brand Image & 0.058 & 0.056 & 0.084 & 0.084 & 0.694 \\
Individual -> Intention & -0.057 & -0.020 & 0.080 & 0.080 & 0.708 \\
\hline
\end{tabular}

As shown in Table 5 and Figure 2, the environmental factors significantly influence the brand image and motivation. This environment variable is divided into two groups, that are reference group (KA) and information exposure (PI). The reference group encompasses the influence of parents (KA1), counseling teachers (KA2), and 
friends (KA3) to choose a college. Meanwhile, the information exposure is from the Internet/website (PI1), Edufair, educational fairs, visit campus and the various colleges (PI2), brochure, print media, posters, magazines and other print media (PI3). An indicator variable of KA2 and PI1 reference group contributed the greatest influence on the environment variable with influence value of 0.839 and 0.777 .

The relationship between the variable of environmental indicator and variable of intention indicator is also explained from the analysis of chi-square test that is from six indicator variables (KA1, KA2, KA3, PI1, PI2, and PI3). There were three indicator variables associated significantly (KA1, KA2, and PI3) with each significant value (pvalue). i.e., 0.045; 0.007; and 0.009 respectively toward the intention of students in choosing college.

Based on this research, motivation and brand image significantly influence the intention of students in choosing the college. The level of motivation is greater than the influence of brand image in influencing the intention of students in choosing IPB ( $\mathrm{p}=$ 0.523). The degree of motivation influence which is great for this intention was also contributed by greater environmental influence toward motivation than toward brand image. On the motivation variable, the students who like science and technology in agriculture (MOTIV5) were accounted for the greatest impact value (0.855) in the variable of motivation among other indicators. The reputable college (B.IMAGE1) contributed the greatest value of influence on the variable of the brand image $(\mathrm{p}=$ $0.825)$.

The results also showed individual, environmental and personality characteristics that did not influence the intention of the students in choosing the college. Based on analysis of chi-square test, the results showed that economic conditions (KE) correlate with students' intention in choosing IPB $(p=0.000)$ and gender $(\mathrm{JK})$ does not correlate significantly with students' intention in choosing IPB (p $=0.767)$.

Based on the calculation of the average value of the indicator variable scores, students have a tendency of Conscientiousness (3.55), Extraversion (3.55), and Openness (3.46) as well. The conscientiousness personality is characterized when someone who is regular, hard-working, reliable, punctual, neat, ambitious are also always discipline. An extraversion person is sociable, active, talkative, optimistic, and cheerful. Meanwhile, openness personality is characterized by a great curiosity, intention, creativity, imagination, and modernity. According to the analysis of chisquare of 15 indicators of personality, there were two indicators that had a significant relationship with the intention to choose IPB, namely OPENNES1 (have originality and often comes up with new ideas) with a p-value of 0.042 and OPENNES2 (curiosity high on many things) with a p-value of 0.033 . 


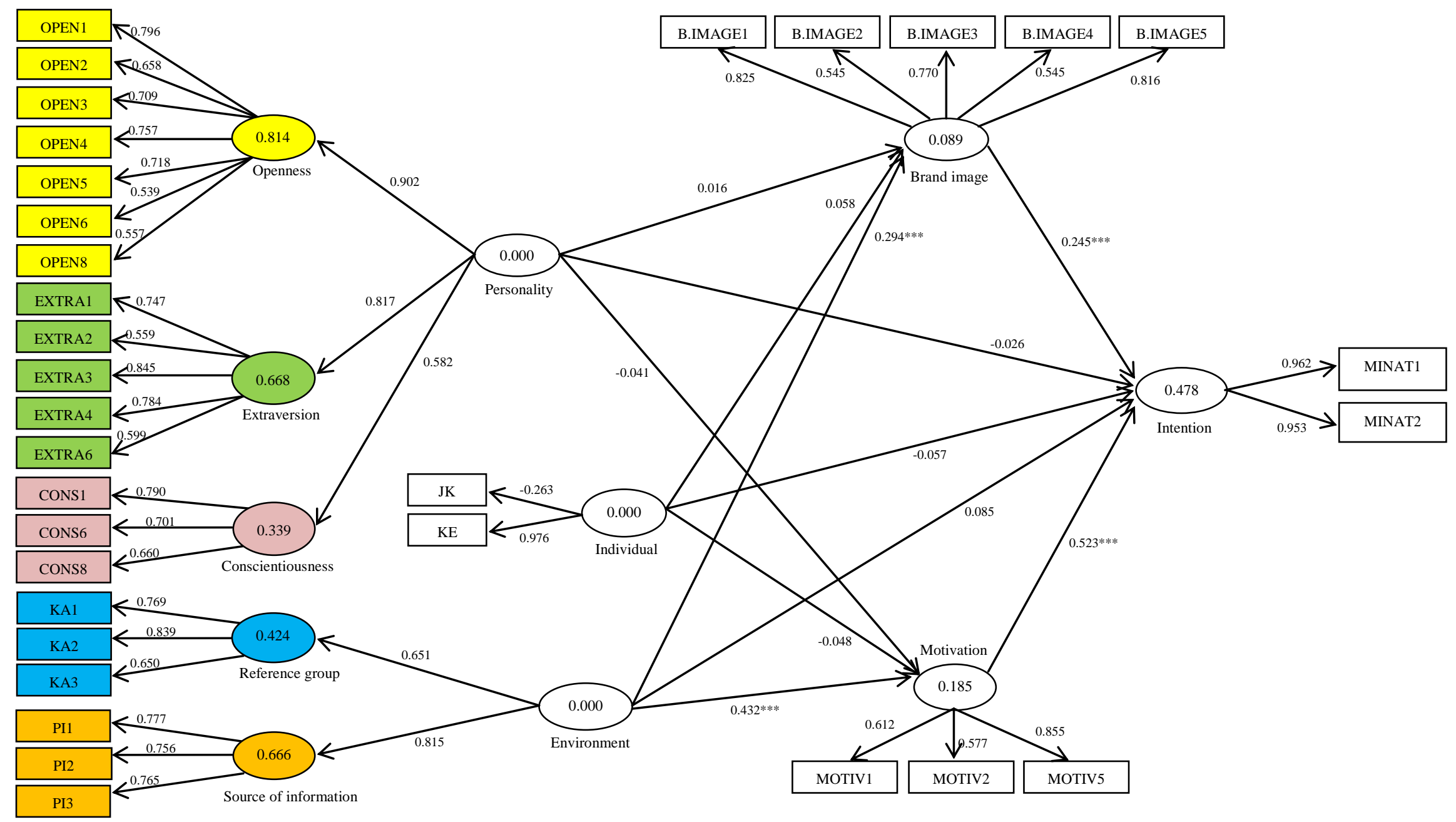

Figure 2 The result of Structural Equation Modeling (SEM) analysis 


\section{Discussion}

College voting behavior of students indicates the desire of students in choosing a college where the order of the college is according to their interest, perceptions of brand image, knowledge, and sources of information about the college. The reason for students in choosing UI and ITB as the first and second college rank was quite alike. This means that both colleges have a special perception from the students.

In the perception of the brand image of the college, the highest average score was IPB. This was because the students believe IPB as a good brand image of agriculture and has an affordable cost of education. Thus, it contributes to the highest average scores on the brand image of students perception to IPB. Moreover, IPB has core competence on agriculture and the cost of education are relatively affordable compared to four other colleges. The average score of students on the brand image of other colleges was the smallest because not all students take other colleges as an option.

Students' answers related to the option of selecting IPB showed a significant relationship between the order of selection towards students' desire to choose IPB. This means that students do not make the IPB as a sequence of first choice college.

The test of measurement model (outer model) shows that some of the indicators used have good reliability - capable of measuring its construct, have good divergent validity, but some indicators such as variables of latent personality, motivation, environment and openness have a convergent validity which is quite weak. This happens because of the possibility of error which cannot be described in the research model. This became the limitations of the research model (Ghozali, 2008).

The result of structural model tests (inner model) shows that the model was qualified as a moderate structural model which $\mathrm{R}$ square value was 0.4781 . It was considered as good enough because the variability of the endogenous variables can be explained by the variability of the exogenous variables as much as 47.81 percent. The research with the data cross section value of 40 percent is considered high enough (Ghozali, 2006).

Based on the coefficient of lanes and significant value in the model, environmental factors significantly influenced brand image and motivation. This means that these environmental factors contributed an indirect influence on the intention to choose IPB through motivation and brand image. Therefore, the higher the influence of the environment, the higher the students' motivation and brand image to be more interested in choosing IPB. The value of environmental influences on motivation was greater than its impact on brand image.

The environmental factor is divided into two groups, namely reference group (KA) and information exposure (PI). The indicators are KA1 (influential parents in college selection), KA2 (significantly influential counseling teachers in college selection), KA3 (a greatly influential college selection), PI1 (frequent access on Internet/website), PI2 (frequent attendance to Edufair, educational fairs, campus visits, and research completion on the various colleges), and PI3 (information gathering from the brochure, print media, posters, magazines and other written media). Information exposure (e.g. campus visits, the internet and media writing) influencing the students in choosing a college is also found in the studies of Burns (2006); Kim, Won, and Cho (2011); Daily, Farewell, and Kumar (2010); Sawaji, Hamzah, and Taba (2010); Ming (2010); Pushkar, Kumar, and Surenthira (2013); Kitsawad (2013), Shammot (2011); Herren, Catwell, and Robertson (2011); and Fernandez (2010). Furthermore, the results 
of Kim and Periyayya's research (2013) on students expectations and branding strategies in private higher education in Malaysia showed the effectiveness scores of media campaigns internet, newspapers, magazines, brochures, educational exhibits (high school visit), electronic media, television, radio, word of mouth, posters, and photographs.

Counseling teachers and the internet access contributed the greatest influence on the environment factor with a value of 0.839 and 0.777 , respectively. This means that the higher the influence of counseling teachers and the more frequent the students access the Internet/website, the higher the students' motivation and brand image ultimately increase their intention to choose IPB. Counseling teachers influencing the choice of the students was also found in the studies of Azubuike (2011); Kyalo and Chumba (2011); Tran (2012); Herren, Cartwell, and Robertson (2011), but did not significantly influence the research of Kitsawad (2013). Besides, the influence of family and/or friends are found in the research of Sawaji, Hamzah, and Taba (2010); Tran (2012); Temple (2009); Nassif (2011); Sojkin, Bartkowiak, and Skuza (2012); Herren, Cartwell, and Robertson (2011); and Razak (2008). Conversely, family and friends did not significantly influence the students' intention on college as found by Burns (2006), and Adams and Salome (201).

The results also showed that motivation and brand image significantly influenced the intention of the students to choose IPB. The influence of motivation is greater than the influence of brand image in the intentions of students to choose IPB (pvalue $=0.523$ ). Great motivational influence on the intention of students was also caused by greater environmental influences on motivation compared to the brand image. The students' joy on agricultural science and technology (MOTIV5) accounted for the greatest influence $(\mathrm{p}$-value $=0.855)$ compared to the location close to home (MOTIV1) and the ease of getting a scholarship (MOTIV2). Location influences the college selection (Ming, 2010; Pushkar, Kumar and Surenthira, 2013; Nassif, 2011; McCarthy, Sen, and Garrity, 2012). Financial assistance such as scholarships has an influence on college selection (Daily, Farewell, and Kumar, 2010; Ming, 2010; Brown, McClary, and Bellingar, 2013, Shammot, 2011). The influence of research program was found in the studies of Ming (2010), Pushkar, Kumar and Surenthira (2013), and Fernandez (2010). According to the research of Eidri (2009) on high school students in Bogor, IPB was described as a college with a comfortable environment, scholarship programs, an affordable tuition, and strategic campus locations.

Reputable college (B.IMAGE1) is accounted for the greatest influence on the brand image which was equal to 0.825 . This means that the greater activity or IPB's effort to increase student motivation, especially related to the increase of their joy in science and technology in agriculture, would increase their intention to choose IPB. Similarly, greater efforts to improve the brand image of IPB's students, especially related to the positive reputation of the college, would also increase their intention to choose IPB. The results of reputable college in increasing students' intention to choose the college is in line with the research of Daily, Farewell, and Kumar (2010); Ming (2010); Pushkar, Kumar, and Surenthira (2013); Shammot (2011); Zain, Jan, and Ibrahim (2013); Furukawa (2011); Herren, Catwell, and Robertson (2011); Fernandez (2010); and McCarthy, Sen, and Garrity (2012), but did not influence the image of the United States where the college was located.

The results also showed that the characteristics of the individual, environment, and personality did not influence the students' intention to choose the college. The 
socioeconomic conditions influenced the college selection as found in the research of Azubuike (2011); Razak (2008); Kyalo and Chumba (2011); Andanawari (2010); Stater (2011); and Nassif (2011). Conversely, students' gender did not have a real significant effect (Kim, Won, and Cho, 2011; Kyalo and Chumba, 2011; Shammot, 2011) as well as the teachers' gender (Adams and Salome, 2014).

In some other research, personality dimensions, The Big Five Personality Traits can be a predictor in choosing study program and an important consideration when choosing a career (Imperial, 2013), in performing creativity of members of the House of Representatives (DPR) (Widhiastuti, 2014), in adjusting psychologically for foreign students (Adelia and Eliana, 2012), the adjustment of foreign students (Shaifa and Supriyadi, 2013), and in predicting the students' academic maturity (Althoff, 2010). The research model of the relationships between personality and study programs selection, college selection, and particular performance, generally was observed directly in a psychological assessment to determine one's personal and not in complex models as conducted in this study. Therefore, to identify the relationship between students' personality and their interest in choosing a particular college, it is needed to construct the assessment exclusively with college students as the students.

Another research stated that the psychographic variables of The Big Five Personality Traits showed no correlation with the variable intention to buy and find information on the Internet (Joanna, 2007). No correlation could be due to the ease of finding information and purchasing. The easier getting the information about the advantages and drawbacks of goods and services, the more references or alternatives consumers have.

\section{Conclusion and Recommendation}

\section{Conclusion}

Based on these studies, it can be concluded that one-third of the top 15 high school students was intended to choose Bogor Agricultural University (IPB) as the first and second choices. However, students choosing University of Indonesia (UI) as the first and second option was of the highest order. The brand image and motivation significantly and positively influenced students' intention in choosing IPB. Environmental, personality and individual characteristics did not influence students' intention. Environment significantly and positively influenced brand image and motivation of the best 15 high school students in choosing IPB. Individual and personality characteristics had no influences on motivation, brand image, and intention. Motivation becomes a factor that mostly influence the intention of top 15 best high school students in choosing IPB.

\section{Recommendation}

Managerial implications that can be recommended based on the above results to the Bogor Agricultural University (IPB) is shown in Table 6. 
Table 6 Managerial implications that can be recommended based on the results

\begin{tabular}{|c|c|}
\hline Results & Managerial implication \\
\hline $\begin{array}{l}\text { Brand image influences intention } \\
-\quad \text { Reputable college }\end{array}$ & $\begin{array}{l}\text { - Improving the positive reputation by improving the } \\
\text { dissemination of information about the advantages of } \\
\text { IPB to various mass media channels, selecting the } \\
\text { marketable name of the study program without } \\
\text { decrease the competence or the substance. } \\
\text { - Making quick respond to the crisis of negative issues } \\
\text { that lower IPB's reputation }\end{array}$ \\
\hline $\begin{array}{l}\text { Motivation influences intention } \\
\text { - Liking the field of science and } \\
\text { technology in agriculture }\end{array}$ & $\begin{array}{l}\text { - Enhancing the students love of science and } \\
\text { technology in agriculture through various activities } \\
\text { related to agriculture } \\
\text { - Advocating for agricultural policy at the national } \\
\text { level so that the government will get involved in } \\
\text { socializing the important role of agriculture for } \\
\text { mankind }\end{array}$ \\
\hline $\begin{array}{l}\text { Environment influences indirectly on int } \\
\text { a. Reference group } \\
\text { - Consideration of counseling } \\
\text { teachers is a great influence on } \\
\text { choosing college } \\
\text { b. Information exposure } \\
\text { - Frequently access the Internet / } \\
\text { website }\end{array}$ & $\begin{array}{l}\text { through motivation and brand image } \\
\text { a. Maintaining personal relationships with counseling } \\
\text { teachers through intensive communication (provision } \\
\text { of information, specialized training, special } \\
\text { invitations tips to entry IPB), and make a deal, if } \\
\text { necessary, the Memorandum of Understanding } \\
\text { (MoU) with the school through counseling teachers of } \\
\text { the quota of students who received IPB from SMA } \\
\text { PERAKS and requirements of IPB's special entrance } \\
\text { invitation. } \\
\text { breating the attractive websites in order to attract } \\
\text { more students and increasing promotion through } \\
\text { various social media networks that are favored by } \\
\text { students. }\end{array}$ \\
\hline
\end{tabular}

\section{Reference}

Adams, A., \& Salome, A. A. (2014). Factors affecting the choice of science subjects among female students in Jigawa Metropolis, Nigeria. Creative Education, 5(14). 1296-1304. doi: 10.4236/ce.2014.514148.

Adelia, C. I., \& Eliana, R. (2012). Peran dimensi kepribadian big five terhadap penyesuaian psikologis pada mahasiswa Indonesia yang studi keluar negeri [The role of big five personality dimensions to psychological adjustment on Indonesian students who study abroad] Psikologia-online, 7(2), 74-80. Retrieved from http://jurnal.usu.ac.id/index.php/psikologia/article/view/1351/728.

Alma, B., \& Hurriyati, R. (2008). Manajemen Corporate dan Strategi Pemasaran Jasa Pendidikan: Fokus pada Mutu dan Layanan Prima [Corporate Management and Services Marketing Strategy: Focus on Superfine Quality Education and Services]. Bandung, Indonesia: Alfabeta. 
Althoff, R. W. (2010). The big five personality traits as predictors of academic maturity (Master's thesis). Retrieved from http://thekeep.eiu.edu/theses/605/.

Andanawari, A. G. (2010). Faktor-faktor yang mempengaruhi minat siswa melanjutkan pendidikan ke perguruan tinggi dengan menggunakan regresi logistik (Studi kasus: Minat siswa SMU/sederajat di Kabupaten Garut terhadap STAI Al-Musaddadiyah) [Factors that affect the interests of the students continue their education to college using logistic regression (Case study: The interest of high school students in Garut to Al-Musaddadiyah Islamic Religious School)] (Undergraduate thesis). Retrieved from http://repository.ipb.ac.id/handle/123456789/55975.

Anderson II, J. C. (2013). An exploration of the motivational profile of secondary urban agriculture students. Journal of Agricultural Education, 54(2), 205-216.

Azubuike, O. C. (2011). Influential factors affecting the attitude of students towards vocational/technical subjects in secondary schools in Southeastern Nigeria. Journal of Educational and Social Research, 1(2), 49-56.

Brown, C. C., McClary, A., \& Bellingar, J. (2013). Determinants of student demand at Florida Southern College. Journal of Case Research in Business and Economics, 4, 1-9. Retrived from http://www.aabri.com/manuscripts/11861.pdf.

Burns, M. J. (2006). Factors influencing the college choice of African-American students admitted to the College of Agriculture, Food and National Resources (Master's thesis). Retrieved from https://mospace.umsystem.edu/xmlui/bitstream/handle/10355/4646/research.pdf?seq uence $=3$.

Chozin, M. A. (2008). Penurunan minat terhadap bidang keahlian pertanian di Indonesia: sebuah ironi yang perlu solusi [The interest decline in the field of agricultural expertise in Indonesia: an irony that needs a solution]. Retrieved from https://awangmaharijaya.wordpress.com/2008/02/22/penurunan-minat-terhadapbidang-keahlian-pertanian-di-indonesia-sebuah-ironi-yang-perlu-solusi/.

Forlapdikti. (2014). Jumlah perguruan tinggi [Number of college]. Retrieved from http://forlap.dikti.go.id/perguruantinggi/homegraphpt.

Gitonga, C., Meru, R. S., Orodho, J. A., Tabitha, W., \& Edward, K. (2014). Is the choice of a degree program a factor of personality types and degree of congruence. IOSR Journal of Humanities and Social Science (IOSR-JHSS), 19(2), 49-54. Retrieved from http://iosrjournals.org/iosr-jhss/papers/Vol19-issue2/Version5/H019254954.pdf.

Daily, C. M., Farewell, S., \& Kumar, G. (2010). Factors influencing the university selection of international students. Academy of Educational Leadership Journal, 14(3), 59-75.

Eidri, T. M. (2009). Analisis positioning Institut Pertanian Bogor berdasarkan persepsi siswa-siswi SMU di Bogor [Positioning analysis of Bogor Agricultural University based on the perception of high school students in Bogor] (Undergraduate thesis). Retrieved from http://repository.ipb.ac.id/handle/123456789/15081.

Eidimtas, A. \& Juceviciene, P. (2014). Factors influencing school-leavers decision to enrol in higher education. Procedia-Social and Behavioral Sciences, 116, 39833988. doi: 10.1016/j.sbspro.2014.01.877.

Esters, L. T. \& Bowen, B. E. (2005). Factors influencing career choice of urban agricultural education students. Journal of Agricultural Education, 46(2), 24-35. doi: $10.5032 /$ jae.2005.02024. 
Fernandez, J. L. (2010). An exploratory study of factors influencing the decision of students to study at Universiti Sains Malaysian. Kajian Malaysia, 28(2), 107-136. Retrieved from http://web.usm.my/km/28(2)2010/KM\%20ART\%204(107-136).pdf.

Fosu, F. F., \& Poku, K. (2014). Exploring the factors that influence students' choice of higher education in Ghana. European Journal of Business and Management, 6(28), 209-220. Retrieved

from http://www.iiste.org/Journals/index.php/EJBM/article/view/16020/16215.

Fritz, S., Husmann, D. E., Reese, D., Stowell, R., \& Powell, L. A. (2007). High school students' perceptions of a college of agricultural sciences and natural resources. Papers in Natural Resources Paper 438. Retrieved from $\mathrm{http} / /$ digitalcommons.unl.edu/natrespapers/438.

Furukawa, D. T. (2011). College choice influences among high-achieving students: an exploratory case study of college freshmen (Doctoral dissertation). Retrieved from http://digitalscholarship.unlv.edu/cgi/viewcontent.cgi?article=2092\&context=theses dissertations.

Ghozali, I. (2008). Structural Equation Modeling Metode Alternatif dengan Partial Least Square [Structural Equation Modeling Alternative Method with Partial Least Square] (2nd ed.). Semarang, Indonesia: Badan Penerbit Universitas Diponegoro.

Herren, C. D., Cartmell II, D., \& Robertson, J. T. (2011). Perceptions of influence on college choice by students enrolled in a college of agricultural sciences and natural resources. North American College and Searchs of Agriculture (NACTA) Journal, 54-60.

Imperial, S. E. (2013). College major selection and personality variables as determinants in lifelong career decision-making (Master's thesis). Retrieved from http://centralspace.ucmo.edu/bitstream/handle/123456789/303/Imperial_PSYCHOL OGY.pdf? sequence $=1$.

Institut Pertanian Bogor. (2013a). Statistika Pendidikan Institut Pertanian Bogor Tahun 2013 [Education Statistics of Bogor Agricultural University in 2013]. Bogor, Indonesia: Direktorat Administrasi dan Pendidikan IPB.

Institut Pertanian Bogor. (2013b). Rencana Strategis IPB 2013-2018 [IPB Strategic Plan in 2013-2018)]. Bogor, Indonesia. IPB Press.

Joanna, C. H. S. (2007). Online information search and purchace: the influence of demographics and psychographics (Undergraduate thesis). Retrieved from http://libproject.hkbu.edu.hk/trsimage/hp/05005973.pdf.

Kim, V. W. E., \& Periyayya, T. (2013). Student expectations and branding strategies among private institutions of higher education in Malaysia. Malaysian Journal of Chinese Studies, 2(1), 69-81. Retrieved from http://www.newera.edu.my/files/mces/MalaysianJournal/Malaysia\%20Journal\%20V ol\%202_4.pdf.

Kim, J., Kwon, Y., \& Cho, D. (2011). Investigating factors that influence social presence and learning outcomes in distance higher education. Computers and Education, 57(2), 1512-1520. doi: 10.1016/j.compedu.2011.02.005.

Kitsawad, K. (2013). An investigation of factors affecting high school student's choice of university in Thailand (Doctoral dissertation). Retrieved from http://ro.uow.edu.au/cgi/viewcontent.cgi?article $=4783 \&$ context $=$ theses.

Kotler, P., \& Andreasen, A. R. (1995). Strategi Pemasaran untuk Organisasi Nirlaba [Marketing Strategies for Nonprofit Organizations] (3rd ed.). (Emilia, O., Trans.). Yogyakarta, Indonesia: Gadjah Mada University Press. 
Kyalo, P. M., \& Chumba, R. J. (2011). Selected factors influencing social and academic adjustment of undergraduate students of Egerton College: Njoro Campus. International Journal of Business and Social Science, 2(18), 274-290. Retrieved from http://ijbssnet.com/journals/Vol_2_No_18_October_2011/33.pdf.

Lee, S. J., \& Chatfield, H. K. (2011). The Analysis of factors affecting choice of college: A case study of UNLV hotel college students. Retrieved from http://scholarworks.umass.edu/gradconf_hospitality/2011/Presentation/17/.

Manuwoto, S., Gunawan, A., \& Firdaus, M. (2010). Fenomena Penurunan Peminat Perguruan Tinggi Pertanian Indonesia [The decline phenomenon of applicant of Indonesian college of agriculture]. Bogor, Indonesia: IPB Press.

Martini. (2013). Analisa faktor-faktor yang mempengaruhi pemilihan jurusan akuntansi sebagai tempat kuliah di perguruan tinggi [Analysis of the factors that influence the selection of the accounting department as a place to go to college]. Jurnal Manajemen Fakultas Ekonomi Universitas Budi Luhur, 1(1), 1-19.

McCarthy, E. E., Sen, A. K., \& Garrity, B. F. (2012). Factors that influence Canadian students' choice of higher education institutions in the United States. Business Education \& Accreditation, 4(2), 85-95.

McEown, M. S., Noels, K. A., \& Saumure, K. D. (2014). Students' self-determined and integrative orientations and teachers' motivational support in a Japanese as a foreign language context. System 45, 227-241. doi: 10.1016/j.system.2014.06.001.

Ming, J. S. K. (2010). Institutional factors influencing students' college choice decision in Malaysia: A conceptual framework. International Journal of Business and Social Science, 1(3), 53-58. Retrieved from http://www.ijbssnet.com/journals/Vol._1_No._3_December_2010/6.pdf.

Misran, N., Sahuri, S. N. S., Arsad, N., Hussain, H., Zaki, W. M. D., \& Aziz, N. A. (2012). The influence of socio-economic status among matriculation students in selecting university and undergraduate program. Procedia-Social and Behavioral Sciences, 56, 134-140. doi: 10.1016/j.sbspro.2012.09.640.

Nassif, S. M. A. (2011). Self-reported factors that influence choice of college-bound students in Lebanon (Doctoral dissertation). Capella University, Lebanon.

Onu, F. M., \& Ikehi, M. E. (2013). Factors influencing students' choice to study agricultural science in South-South Nigeria. Journal of Agriculture and Biodiversity Research, 2(4), 80-86. Retrieved from http://onlineresearchjournals.org/JABR/pdf/2013/may/Onu\%20and\%20Ikehi.pdf.

Pushkar, D., Kumar, S. S., \& Surenthiran, N. (2013). Factors affecting choice of engineering colleges in Odisha, India. Research Journal of Management Sciences, 2(4), 14-20. Retrieved from http://www.isca.in/IJMS/Archive/v2i4/3.ISCA-RJMS2013-023.pdf.

Razak, M. (2008). Analisis proses pengambilan keputusan mahasiswa dalam memilih program studi pada PTS di Sulawesi Selatan [Analysis of the decision-making process of the students in choosing courses at private universities in South Sulawesi]. Social and Culture, Reference Group, Marketing Communication.

Ristiyanti, P., \& Ihalauw, J. J. O. I. (2005). Perilaku Konsumen [Consumer Behavior] (1st ed.). Yogyakarta, Indonesia: Andi.

Sawaji, J., Hamzah, D., \& Taba, I. (2010). Pengambilan keputusan mahasiswa dalam memilih perguruan tinggi swasta di Sulawesi Selatan [Students' decision-making in choosing a private university in South Sulawesi]. Retrieved from http://pasca.unhas.ac.id/jurnal/files/93eafc626f1884778a6b787f77c1832b.pdf. 
Schiffman, T., \& Kanuk, L. (2007). Perilaku Konsumen [Consumer Behavior] (7th ed.). Jakarta, Indonesia: Indeks.

Shaifa, D., \& Supriyadi. (2013). Hubungan dimensi kepribadian the big five personality dengan penyesuaian diri mahasiswa asing di Universitas Udayana [Relationships between the big five personality dimensions and self-adjustment of foreign students at the Udayana University]. Jurnal Psikologi Udayana, 1(1), 72-83. Retrieved from http://ojs.unud.ac.id/index.php/psikologi/article/view/8485.

Shammot, M. M. (2011). Factors affecting the Jordanian students' selection decision among private universities. Journal of Business Studies Quarterly, 2(3), 57-63.

Smith, J. (2010). Differences in personality factors and college major choice (Master's thesis). Rochester Institute of Technology, New York.

Sojkin, B., Bartkowiak, P., \& Skuza, A. (2012). Determinats of higher education choices and student satisfaction: The case of Poland. Higher Education, 63(5), 565581.

Srinadi, I. G. A. M., \& Nilakusmawati, D. P. E. (2008). Faktor-faktor penentu kepuasan mahasiswa terhadap pelayanan fakultas sebagai lembaga pendidikan [Predictor factors of student satisfaction on the faculty services as an educational institution]. Cakrawala Pendidikan, (3), 217-231. Retrieved from http://journal.uny.ac.id/index.php/cp/article/view/322.

Stater, M. (2011). Financial aid, student background, and the choice of first-year college major. Eastern Economic Journal, 37(3), 321-343. doi: 10.1057/eej.2009.41.

Temple, S. L. (2009). Factors that influence students' desires to attend higher education (Doctoral dissertation). Retrieved from http://scholarship.shu.edu/cgi/viewcontent.cgi? article=1420\&context=dissertations.

Tran, H. (2012). Factors that influence college choice and pathways among Vietnamese American high school students (Doctoral dissertation). Retrieved from http://eaop.ucsd.edu/198/groupidentity/Factors $\% 20$ that $\% 20$ influence $\% 20$ college $\% 20$ choice $\% 20$ and $\% 20$ pathways $\% 20$ among\%20Vietnamese $\% 20$ American\%20high\%20school\%20students.pdf.

Vrontis, D., Thrassou, A., \& Melanthiou, Y. (2007). A contemporary higher education student-choice model for developed countries. Journal of Business Research, 60(9), 979-989. doi: 10.1016/j.jbusres.2007.01.023.

Wagner, K., \& Fard, P. Y. (2009). Factors influencing Malaysian students intention to study at a higher education. Retrieved from www.gcasa.com/PDF/malaysia/Wagner-Fard.pdf.

Widhiastuti, H. (2014). Big five personality sebagai prediktor kreativitas dalam meningkatkan kinerja anggota dewan [Big five personality as a predictor of creativity in improving the performance of councilors]. Jurnal Psikologi, 41(1), 115-133. Retrieved from http://jurnal.ugm.ac.id/jpsi/article/view/6962/5423.

Wijaya, D. (2012). Pemasaran Jasa Pendidikan [Marketing Educational Services]. Jakarta, Indonesia: Salemba Empat.

Zain, O. M., Jan, M. T., \& Ibrahim, A. B. (2013). Factors influencing students' decision in choosing private institutions of higher education in Malaysia: a structural equation modelling approch. Asian Academy of Management Journal, 18(1), 75-90. Retrieved from http://web.usm.my/aamj/18012013/AAMJ180205.pdf.

Zubaidah, N. (2013). Mahasiswa jurusan teknologi minim, beasiswa dialihkan [Students majoring in minimal technology, scholarship diverted]. Sidonews.com. Retrieved 
from http://nasional.sindonews.com/read/780385/15/mahasiswa-jurusan-teknologiminim-beasiswa-dialihkan-1378534208. 